Chapman University

Chapman University Digital Commons

Food Science Faculty Articles and Research

Science and Technology Faculty Articles and

Research

8-23-2018

Interactions Between Mushroom Powder, Sodium Chloride, and Bovine Proteins and Their Effects on Lipid Oxidation Products and Consumer Acceptability

Natalie Tom

Hatouf Ahmed Alnoumani

Lilian Were

Follow this and additional works at: https://digitalcommons.chapman.edu/food_science_articles

Part of the Food Chemistry Commons, Food Processing Commons, Meat Science Commons, and the Other Food Science Commons 


\section{Interactions Between Mushroom Powder, Sodium Chloride, and Bovine Proteins and Their Effects on Lipid Oxidation Products and Consumer Acceptability}

\section{Comments}

NOTICE: this is the author's version of a work that was accepted for publication in LWT - Food Science and Technology. Changes resulting from the publishing process, such as peer review, editing, corrections, structural formatting, and other quality control mechanisms may not be reflected in this document. Changes may have been made to this work since it was submitted for publication. A definitive version will be subsequently published in LWT - Food Science and Technology in 2018. DOI: 10.1016/j.lwt.2018.08.044

The Creative Commons license below applies only to this version of the article.

\section{Creative Commons License} (c) $(i) \Theta \Theta$

This work is licensed under a Creative Commons Attribution-Noncommercial-No Derivative Works 4.0 License.

\section{Copyright}

Elsevier 


\section{Accepted Manuscript}

Interactions between mushroom powder, sodium chloride, and bovine proteins and their effects on lipid oxidation products and consumer acceptability

Natalie Tom, Hatouf Ahmed Alnoumani, Lilian Were

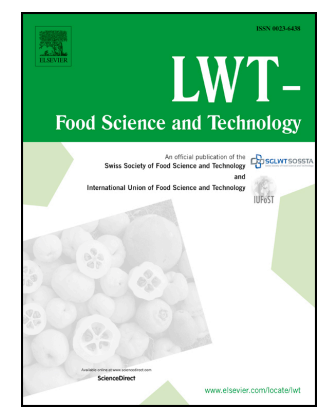

PII:

S0023-6438(18)30696-0

DOI:

10.1016/j.Iwt.2018.08.044

Reference: YFSTL 7356

To appear in: $\quad$ LWT - Food Science and Technology

Received Date: 19 April 2018

Revised Date: 15 July 2018

Accepted Date: 23 August 2018

Please cite this article as: Tom, N., Alnoumani, H.A., Were, L., Interactions between mushroom powder, sodium chloride, and bovine proteins and their effects on lipid oxidation products and consumer acceptability, LWT - Food Science and Technology (2018), doi: 10.1016/j.Iwt.2018.08.044.

This is a PDF file of an unedited manuscript that has been accepted for publication. As a service to our customers we are providing this early version of the manuscript. The manuscript will undergo copyediting, typesetting, and review of the resulting proof before it is published in its final form. Please note that during the production process errors may be discovered which could affect the content, and all legal disclaimers that apply to the journal pertain. 
Interactions between mushroom powder, sodium chloride, and bovine proteins and their effects on lipid oxidation products and consumer acceptability

3

4

5

6

Food Science Program, Schmid College of Science and Technology, Chapman University,

$12 *$ Contact information for corresponding author:

13 E-mail: were@ chapman.edu

14 Address: Food Science Program, Schmid College of Science and Technology, Chapman

15 University, 1 University Drive, Orange, CA 92866

16 Telephone: (714) 744-7895

Fax Number: 714-532-6048

18

19 


\section{Abstract}

The antioxidant capacity of dried Agaricus bisporus mushrooms (DAB) in beef has previously been assessed. However, interactions between lipid oxidation products, mushroom polyphenols, and bovine proteins present in beef to explain the mushroom's antioxidative effect, has not been determined. Oven-dried or lyophilized DAB with and without $15 \mathrm{~g} \mathrm{NaCl} / \mathrm{kg}$ beef $(1.5 \%)$ or $20 \mathrm{~g} \mathrm{NaCl} / \mathrm{kg}$ beef $(2 \%)$ were added to sarcoplasmic protein homogenates from top round beef. Malondialdehyde and volatile aldehyde binding to sarcoplasmic protein (SP) were monitored. Oven dried had $64 \%$ higher total phenolic compared to lyophilized DAB, leading to $\sim 50 \%$ lower malondialdehyde content in beef with oven dried DAB compared to lyophilized DAB. The addition of $20 \mathrm{~g} \mathrm{NaCl} / \mathrm{kg}$ beef (2\%) acted as a pro-oxidant, while addition of $15 \mathrm{~g}$ $\mathrm{NaCl} / \mathrm{kg}$ beef $(1.5 \%)$ increased binding of lipid oxidation (LOX) products to SP. The results suggest that addition of mushrooms to beef can enhance the binding of sarcoplasmic protein to lipid oxidation products, thereby decreasing lipid oxidation compounds.

Keywords: Agaricus bisporus; aldehyde binding; sarcoplasmic proteins; sodium reduction 


\section{Introduction}

Lipid oxidation begins immediately after beef slaughter and compromises the quality of beef over time by producing volatile aldehydes that contribute to the development of rancid offflavors and odors, thereby limiting the overall consumer acceptability (Sammet, Duehlmeier, Sallmann, Von Canstein, Von Mueffling, \& Nowak, 2006). In the USA, the estimated supermarket shrinkage (food loss) resulting in uneaten meat from 2011-2012 was about 13 percent which was three times higher than the 4.5 percent shrinkage from 2005-2006 (Buzby, Bentley, Padera, Campuzano, \& Ammon, 2016). This shrinkage may partially be due to changes in color and production of off aromas, which are indicators of freshness in beef products for consumers (Font-I-Furnols \& Guerrero, 2014).

Secondary products of lipid oxidation, which include malondialdehyde (MDA) and volatile aldehydes such as propanal formed by oxidation of linolenic acid, hexanal formed by oxidation of linoleic acid, and octanal formed from oxidation of oleic acid (Pavan \& Duckett, 2013) are responsible for the development of rancid off-flavors and aromas that consumers often associate with spoilage and the increasing shrinkage. To inhibit lipid oxidation in ground beef, natural plant-based extracts rich in antioxidants, such as rosemary, have been used. Agaricus bisporus mushrooms (DAB) contain antioxidant phenolic and ergothioneine compounds (Dubost, Ou, \& Beelman, 2007), making these Agaricus bisporus mushrooms a readily available source of antioxidants to inhibit lipid oxidation and prolong shelf life stability of foods.

Alnoumani, Ataman, \& Were (2017) found that ground cooked beef with DAB had 6696\% lower free MDA when compared to the control. The antioxidant capacity of DAB compared to rosemary also increased over time, indicating that mushrooms can be a good alternative to rosemary (Alnoumani et al, 2017). Agaricus bisporus mushrooms have been added to beef to 
inhibit oxidation through radical scavenging from phenolic compounds, however, the degree to which these mushrooms affect the interaction of specific bovine proteins in beef, such as sarcoplasmic protein, to influence lipid oxidation products has not been studied. Thus, the experimental objective was to investigate the antioxidant capacity of DAB as a function of interaction with beef homogenates containing sarcoplasmic bovine proteins.

\section{Materials and Methods}

\subsection{Ground Beef Preparation and Protein Extraction}

Bovine top round beef was purchased twice (10 lbs each time) from American Beef Packers Incorporation (Chino, CA, USA) from a female Holstein carcass, slaughtered less than 21 hours before transportation in coolers covered with bags of ice to the Chapman University laboratory (26 miles). Meat was then ground through a 3-mm grinding plate attached to a KitchenAid food processor (St. Joseph, MI, USA) and patties were formed.

Sarcoplasmic extraction was done as described by Stapornkul, Prytkova, \& Were (2016). Sarcoplasmic protein was then lyophilized and stored in a $-80^{\circ} \mathrm{C}$ freezer for the duration of the research.

\subsection{Blanching and Dehydration of Mushrooms}

Agaricus bisporus mushrooms grown in Pennsylvania (Country Fresh Mushroom Co., 289 Chambers Road, Toughkenamon, PA, 19374) were obtained from B \& C Fresh Sales (Orange, CA) twice (two $5 \mathrm{lbs}$ boxes of mushrooms, totaling to $10 \mathrm{lbs}$ of mushrooms each time).

Mushrooms were washed under a narrow stream of tap water for 5-10 sec. All mushrooms were blanched by placing one layer of mushrooms in a steam basket located $76.2 \mathrm{~mm}$ above boiling water or in a $1 \mathrm{~g}$ ascorbic acid/100 $\mathrm{mL}$ water (1\%) solution for $6 \mathrm{~min}$ to inactivate polyphenol oxidase that could contribute to browning (Lespinard, Goni, Salgado, \& Mascheroni, 2009). 
81

After 6 min of blanching, mushrooms were then placed in either cold water or ascorbic acid solution ( $1 \mathrm{~g}$ ascorbic acid/100 $\mathrm{ml}$ water) for an additional $6 \mathrm{~min}$. Half of the blanched mushrooms were oven dried at $60^{\circ} \mathrm{C}$ for $20 \mathrm{hr}$, and the other half were lyophilized with a Harvest Right Scientific Freeze-Dryer (North Salt Lake, UT, USA) as per manufacturer's instructions using the Food Profile parameters. The dried mushrooms were ground into fine powder using a KitchenAid Blade Coffee Grinder (BCG111OB Onyx Black) and sieved through \#40 mesh $(0.841 \mathrm{~mm})$. A composite mix of the powdered mushrooms were stored in amber bottles in a $80^{\circ} \mathrm{C}$ freezer for the duration of the study.

\subsection{Preparation of Beef, $\mathrm{NaCl}$, and Mushroom Treatments}

The treatments consisted of two concentrations of $\mathrm{NaCl}[15 \mathrm{~g} \mathrm{NaCl} / \mathrm{kg}$ beef (1.5\%), $20 \mathrm{~g}$ $\mathrm{NaCl} / \mathrm{kg}$ beef $92 \%)$, two concentrations of mushrooms [10 $\mathrm{g}$ mushroom $/ \mathrm{kg}$ beef (1\%), $20 \mathrm{~g}$ mushroom/kg beef (2\%)], two different dehydration methods of mushrooms (oven dried or lyophilized), and two blanching methods of mushrooms (ascorbic acid or water). Duplicate samples for each treatment were prepared for each of the 5 time-points (Days 1, 3, 6, 9, and 12), resulting in 160 patties for the entire experiment. These different combinations of mushrooms and $\mathrm{NaCl}$ added to ground beef and formed into patties were then used for the different assays.

\subsection{Preparation of Mushroom and NaCl Solutions}

The concentration of Agaricus bisporus mushroom added to bovine proteins were prepared based on concentrations used in initial ground beef from Alnoumani, Ataman, \& Were (2017)'s study. Since ground beef is comprised of $\sim 220 \mathrm{~g}$ protein/ $\mathrm{kg}$ beef and SP accounts for $\sim 300 \mathrm{~g} \mathrm{SP} / \mathrm{kg}$ total muscle protein, addition of $10 \mathrm{~g}$ mushroom/kg beef (1\%) and $20 \mathrm{~g} \mathrm{DAB} / \mathrm{kg}$ beef (2\%) to ground beef equated to adding $3 \mathrm{~g} \mathrm{DAB} / \mathrm{kg}$ beef $(0.3 \%)$ and $6 \mathrm{~g} \mathrm{DAB} / \mathrm{kg}$ beef $(0.6 \%)$ in SP homogenates. Addition of $15 \mathrm{~g} \mathrm{NaCl} / \mathrm{kg}$ beef $(1.5 \%)$ and $20 \mathrm{~g} \mathrm{NaCl} / \mathrm{kg}$ beef (2\%) to 
104

105

106

107

108

109

110

111

112

113

114

115

116

117

118

119

120

121

122

123

124

125

126

ground beef equated to addition of $4.5 \mathrm{~g} \mathrm{NaCl} / \mathrm{kg}$ beef $(0.45 \%)$ and $6 \mathrm{~g} \mathrm{NaCl} / \mathrm{kg}$ beef $(0.6 \%)$ in SP homogenates.

\subsection{Phenolic Quantification in Dehydrated Mushroom Powder}

Gallic acid (0-1.30 mg/L) dissolved in $70 \mathrm{~mL}$ methanol in $100 \mathrm{ml}$ was used for quantification. Dehydrated mushroom powders were dissolved in $70 \%$ methanol and incubated at room temperature for $10 \mathrm{~min}$ based on Su, Zhang, Hou, Zhang, Guo, Huang, et al., (2014) study. All samples were filtered using $0.45 \mu$ m nylon membrane filters and analyzed using a Luna reverse phase C8 column (150 x $4.6 \mathrm{~mm}$, Phenomenex, Torrance, CA) and an Agilent HPLC 1100 series (Agilent Technologies, Waldbronn, Germany) at $30^{\circ} \mathrm{C}$. The solvents used were: $0.1 \mathrm{~mL}$ formic acid/100 mL HPLC water (A) and $0.1 \mathrm{~mL}$ formic acid/100 $\mathrm{mL}(\mathrm{B})$. The gradient employed was $100 \%$ A for $2 \mathrm{~min}, 99.8 \%$ A for $6.0 \mathrm{~min}, 10 \%$ A for $8 \mathrm{~min}$, and $95 \%$ A for $2 \mathrm{~min}$ at a flow rate of $0.2 \mathrm{~mL} / \mathrm{min}$ at $280 \mathrm{~nm}$.

\subsection{Lipid Oxidation Analysis of Bovine Proteins with Mushroom Infusions and Salt}

\subsubsection{Interaction of Mushrooms, Salt, and Bovine Proteins on Malondialdehyde}

Thiobarbituric acid reactive substances (TBARS) in raw ground beef with added oven dried or lyophilized mushroom powder blanched in either $1 \mathrm{~g}$ ascorbic acid/100 mL water $(1 \%)$ ascorbic acid (AA) or HPLC water at $\mathrm{NaCl}$ concentrations of $15 \mathrm{~g} \mathrm{NaCl} / \mathrm{kg}$ beef (1.5\%) or $20 \mathrm{~g}$ $\mathrm{NaCl} / \mathrm{kg}$ beef $(2 \%)$ were measured after refrigerated storage in Ziploc $®$ bags at $4^{\circ} \mathrm{C}$ after days 1 , $3,6,9$, and 12 . TBARS was also performed for $0.066 \mathrm{~g} / \mathrm{mL}$ SP samples with mushroom $[0 \mathrm{~g}$ $\mathrm{DAB} / \mathrm{kg}$ beef (0\%), $3 \mathrm{~g} \mathrm{DAB} / \mathrm{kg}$ beef (0.3), $6 \mathrm{~g} \mathrm{DAB} / \mathrm{kg}$ beef $(0.6 \%)]$ and $\mathrm{NaCl}[(0 \mathrm{~g} \mathrm{NaCl} / \mathrm{kg}$ beef (0\%), $4.5 \mathrm{~g} \mathrm{NaCl} / \mathrm{kg}$ beef (0.45), $6 \mathrm{~g} \mathrm{NaCl} / \mathrm{kg}$ beef $(0.60 \%)]$. The binding of MDA to protein was assessed as outlined by Stapornkul, Prytkova, \& Were (2016) with modifications as follows. The $164 \mu \mathrm{L}$ of 1,1,3,3 -tetramethoxypropane (TMP) was hydrolyzed in $10 \mathrm{~g}$ 
trichloroacetic acid (TCA)/100 $\mathrm{mL}$ DI water at $70^{\circ} \mathrm{C}$ for $15 \mathrm{~min}$ to obtain $0.1 \mathrm{~mol} / \mathrm{L}$ MDA. Serial dilutions were performed to obtain a final concentration of $0.15 \mathrm{mmol} / \mathrm{L}$ MDA. Each sample contained $0.25 \mathrm{~mL}$ of $\mathrm{NaCl}(0 \mathrm{~g} \mathrm{NaCl} / \mathrm{kg}$ beef $(0 \%), 15 \mathrm{~g} \mathrm{NaCl} / \mathrm{kg}$ beef $(1.5 \%)$ or $20 \mathrm{~g} \mathrm{NaCl} / \mathrm{kg}$ beef (2\%), $0.25 \mathrm{~mL}$ of mushroom powder [0, 10 or $20 \mathrm{~g} \mathrm{DAB} / \mathrm{kg}$ beef $(0,1$ or $2 \% \mathrm{DAB})], 0.25$ $\mathrm{mL}$ of $0.15 \mathrm{mmol} / \mathrm{L} \mathrm{MDA}$, and $0.25 \mathrm{~mL}$ of SP bovine protein. The controls for each variable $(0$ $\mathrm{g} \mathrm{NaCl} / \mathrm{kg}$ beef $(0 \%), 0 \mathrm{~g} \mathrm{DAB} / \mathrm{kg}$ beef $(0 \%)$ contained $0.25 \mathrm{~mL}$ of either $\mathrm{NaCl}[0 \mathrm{~g} \mathrm{NaCl} / \mathrm{kg}$ beef (0\%), $15 \mathrm{~g} \mathrm{NaCl} / \mathrm{kg}$ beef (1.5\%), or $20 \mathrm{~g} \mathrm{NaCl} / \mathrm{kg}$ beef (2\%)], $0.25 \mathrm{~mL}$ of mushroom [0 $\mathrm{g}$ $\mathrm{DAB} / \mathrm{kg}$ beef $(0 \%), 10 \mathrm{~g} \mathrm{DAB} / \mathrm{kg}$ beef $(1 \%)$, or $20 \mathrm{~g} \mathrm{DAB} / \mathrm{kg}$ beef $(2 \%)]$, or $0.25 \mathrm{~mL}$ of SP and $0.75 \mathrm{~mL}$ of DI water. All samples were incubated at $4^{\circ} \mathrm{C}$ for $1 \mathrm{hr}$ before day 0 baseline measurements. Each $0.6 \mathrm{~mL}$ of sample was mixed with $0.75 \mathrm{~mL}$ of $10 \mathrm{~g} \mathrm{TCA} / 100 \mathrm{~mL}$ in microcentrifuge tubes, and then centrifuged using an accuSpinTM micro-centrifuge (Pittsburg, PA, USA) at $8000 \mathrm{~g}^{-1}$ for $5 \mathrm{~min}$. The $0.02 \mathrm{~mol} / \mathrm{L}$ TBA: supernatant (1:1) samples were incubated at $60^{\circ} \mathrm{C}$ for $90 \mathrm{~min}$. Absorbance readings at 532 were recorded using a FLUOstar Omega Microplate Reader (BMG Labtech, Cary, NC, USA).

A standard solution of MDA in $10 \mathrm{~g}$ TCA/100 mL was prepared from TMP and standard curves ranging from 0 to $10 \mathrm{mM}$ were used to quantify MDA in homogenates. The bound MDA was expressed as mg bound MDA/ kg SP (Stapornkul, Prytkova, \& Were, 2016).

\subsubsection{Interaction of Mushrooms, Salt, and Bovine Proteins on Volatile Aldehydes}

Volatile aldehyde binding was determined in sarcoplasmic protein homogenates with 10 $\mathrm{g} \mathrm{DAB} / \mathrm{kg}$ beef (1\%) and $20 \mathrm{~g} \mathrm{NaCl} / \mathrm{kg}$ beef (2\%). These concentrations of mushroom and $\mathrm{NaCl}$ were determined based on results from Section 2.6.1, which showed that $10 \mathrm{~g} \mathrm{DAB} / \mathrm{kg}$ beef (1\%) and $20 \mathrm{~g} \mathrm{NaCl} / \mathrm{kg}$ beef (2\%) resulted in higher free MDA production compared to $20 \mathrm{~g} \mathrm{DAB} / \mathrm{kg}$ beef (2\%) and $15 \mathrm{~g} \mathrm{NaCl} / \mathrm{kg}$ beef (1.5\%). The SP homogenates with added mushroom and $\mathrm{NaCl}$ 
were spiked with volatile aldehydes (pentanal, hexanal, and octanal). Volatile aldehydes bound to protein were then measured using gas chromatography, and binding was expressed as mg/g SP (Stapornkul, Prytkova, \& Were, 2016).

\subsection{Consumer acceptability of salt reduced patties with added mushroom powder}

Each 454g of beef and mushroom mixture contained $9.08 \mathrm{~g}$ DAB. To control ground beef with $1.5 \%$ salt, $6.81 \mathrm{~g} \mathrm{NaCl}$ was added, while to the beef and $2 \%$ DAB samples, $4.54 \mathrm{~g} \mathrm{NaCl}(1 \%)$ was added. The ingredients were mixed for two minutes (Hobart, HL 120, Troy, OH, U.S.A), divided into $100 \mathrm{~g}$ portions, formed as $11.5 \mathrm{~cm}$ diameter patties and cooked for $3 \mathrm{~min}$ on each side to an inner temperature of $71^{\circ} \mathrm{C}$ (Rojas \& Brewer, 2007). Each beef patty was divided into eight pieces. Each piece was placed in a small plastic cup coded with a random three digits number. The samples were served around $54^{\circ} \mathrm{C}$. Two sensory evaluations were conducted: in the first one, samples with $2 \% \mathrm{DAB}$ added had $33 \%$ less $\mathrm{NaCl}$ compared to control sample while in the second trial, $\mathrm{NaCl}$ reduction was $50 \%$ in samples with $2 \% \mathrm{DAB}$.

The effect of incubation time on DAB's impact on saltiness, aroma, and acceptability was conducted over 3 days, given that microbial testing was not part of the current study and 3 days was considered microbially safe. Consumers rated the patties using a nine-point liking scale with 0 being dislike extremely and 9 being like extremely (da Silva, da Silva, Ferreira, Minim, da Costa, \& Perez, 2013). Panelists were provided with crackers and water to cleanse their palates in between samples.

\subsection{Statistical Analysis}

Differences in MDA and volatile aldehyde production and binding to sarcoplasmic protein of three mushroom treatments $[0 \mathrm{~g} \mathrm{DAB} / \mathrm{kg}$ beef $(0 \%), 10 \mathrm{~g} \mathrm{DAB} / \mathrm{kg}$ beef $(1 \%)$, and $20 \mathrm{~g}$ $\mathrm{DAB} / \mathrm{kg}$ beef (2\%)], three $\mathrm{NaCl}$ levels $[0 \mathrm{~g} \mathrm{NaCl} / \mathrm{kg}$ beef (0\%), $15 \mathrm{~g} \mathrm{NaCl} / \mathrm{kg}$ beef (1.5\%), and 
173

174

175

176

177

178

179

180

181

182

183

184

185

186

187

188

189

190

191

192

193

194

195

$20 \mathrm{~g} \mathrm{NaCl} / \mathrm{kg}$ beef (2\%) ] and two drying methods of mushrooms (oven dry or lyophilized) combinations were assessed. Differences between treatments were determined by Analysis of Variance (ANOVA) and Tukey's Honest Significant Difference (HSD) test using Statistical Analysis Software (SAS 9.3, Cary, NC, USA). A level of significance of $\alpha=0.05$ was used throughout the study.

\section{Results and Discussions:}

\subsection{Effect of Mushroom Dehydration Method on Phenolic Acid Composition}

After washing, blanching, and drying, the yields of oven dried and lyophilized mushrooms were $8.35 \%$ and $6.59 \%$, respectively, resulting in a $1.79 \%$ higher yield in oven dried mushrooms compared to lyophilized mushrooms. Oven dried mushroom powder had $64.15 \%$ higher total phenolics of $5.227 \mathrm{mg} / \mathrm{g}$ compared to lyophilized mushroom powder at $3.189 \mathrm{mg} / \mathrm{g}$. Alnoumani, Ataman, \& Were (2017) quantified total phenolic content in dry roasted DAB to be $5.45 \mathrm{mg} / \mathrm{g}$ using Folin-Ciocalteu reagent rather than the HPLC method used in this study. Although lyophilization prevents undesirable shrinkage and produces products with high porosity, unchanged nutritional quality, superior aroma and flavor, and color retention (Oikonomopoulou, Krokida, \& Karathanos, 2011), heating at $100^{\circ} \mathrm{C}$ can disrupt the plant cell wall, thereby liberating polyphenolic compounds more easily compared to the raw material (Choi, Lee, Chun, Lee, \& Lee, 2006). Heating mushrooms can decompose polyphenols and decrease their antioxidant activity at high temperatures. However, an increase in phenolic concentration may occur at low heating temperatures due to enhanced extraction when the cell wall is disrupted to release bound polyphenolic compounds (Ferreira, Barros, \& Abreu, 2009). Oven drying is considered a harsher dehydration method, however, the oven dried Agaricus bisporus mushrooms in this study were oven dried at $60^{\circ} \mathrm{C}$ for 20 hours, whereas Giri \& Prasad, (2007) 
used temperatures set $10^{\circ} \mathrm{C}$ higher or used microwave-vacuuming, which lowered phenolic content. When Mphahlele, Fawole, Makunga, \& Opara, (2016) compared lyophilization and oven drying of pomegranate peels, they found that lyophilization yielded a higher phenolic content compared to oven dried, however, the highest temperature reached for lyophilization in their study was $60^{\circ} \mathrm{C}$ for 16 hours, whereas this study reached a maximum temperature of $120^{\circ} \mathrm{C}$, which was twice the temperature of that of Mphahlele, Fawole, Makunga, \& Opara (2016) study. Higher temperature may explain the lower yield and phenolic content in lyophilized mushrooms compared to oven dried mushrooms. Differences in total phenolics and type of phenolics with the different dehydration methods could impact functionality. Gallic acid in oven dried and lyophilized mushrooms was 1.353 and $0.9241 \mathrm{mg} / \mathrm{g}$, respectively. Lyophilization and oven drying at $60^{\circ} \mathrm{C}$ could impact other reducing bioactive compounds besides phenolic compounds. For instance the different dehydrations can affect enzymatic versus non-enzymatic browning which could further affect reducing capacity of the powders.

\subsection{Interactions of Mushroom Powder, NaCl, and Sarcoplasmic Proteins with Lipid Oxidation Products}

\subsubsection{Binding of Malondialdehyde to Bovine Proteins in the Presence of Mushroom} Powder and $\mathrm{NaCl}$

Addition of $20 \mathrm{~g} \mathrm{DAB} / \mathrm{kg}$ beef (2\%) of oven dried and lyophilized DAB decreased free

\section{MDA by 46.51-92.60\% and 56.73-92.77\% in both $15 \mathrm{~g} \mathrm{NaCl} / \mathrm{kg}$ beef $(1.5 \%)$ and $20 \mathrm{~g} \mathrm{NaCl} / \mathrm{kg}$} beef ( $2 \%$ ) salted ground beef, respectively, compared to the control with no DAB on day 12 of refrigerated storage (Fig. 1). For the $15 \mathrm{~g} \mathrm{NaCl} / \mathrm{kg}$ beef (1.5\%) and $20 \mathrm{~g} \mathrm{NaCl} / \mathrm{kg}$ beef (2\%) salted ground beef samples, added oven dried mushroom powder to raw beef lowered MDA compared to lyophilized mushroom powder (Fig. 1) attributed to the $64.15 \%$ higher phenolic content in oven dried mushrooms (section 3.1 and Fig. S2). These mushroom phenolic compounds can donate hydrogens to free radicals and decrease production of lipid oxidation 
products (Ghahremani-Majd \& Dashti, 2015).

The free MDA in the $20 \mathrm{~g} \mathrm{NaCl} / \mathrm{kg}$ beef (2\%) control with no added mushrooms was $34.50 \%$ higher compared to the $15 \mathrm{~g} \mathrm{NaCl} / \mathrm{kg}$ beef (1.5\%) control with no added mushroom powder on day 12 (Fig. 1), with the interaction between salt and treatments being significant ( $<<0.05$ ) (Table 1). Rhee \& Ziprin, (2001) also found that $\mathrm{NaCl}$ at $25 \mathrm{~g} \mathrm{NaCl} / \mathrm{kg}$ beef promoted lipid oxidation. The pro-oxidant action of $\mathrm{NaCl}$ at $20 \mathrm{~g} \mathrm{NaCl} / \mathrm{kg}$ beef (2\%) was attributed to its potential capacity to disrupt cell membrane integrity, facilitating access of free radicals to unsaturated fatty acids, as well as liberating iron ions from heme protein, therefore leaving more free iron ions to catalyze LOX and inhibit antioxidant enzymes (Mariutti \& Bragagnolo, 2017). Further investigations are suggested to pinpoint which of the aforementioned mechanisms explain the pro-oxidant effect at higher $\mathrm{NaCl}$ concentrations.

Since ascorbic acid is an anti-browning agent that can prevent oxidation and discoloration of beef during storage by reduction of metamyoglobin-Fe(III) to metamyoglobin-Fe(II), thereby maintaining the red color in raw beef (Varvara, Bozzo, Celano, Disanto, Pagliarone, \& Celano, 2016), blanching in $1 \mathrm{~g}$ ascorbic acid/100 $\mathrm{mL}$ water solution to inactivate the browning polyphenol oxidase enzyme was compared to that in water. In beef with $15 \mathrm{~g} \mathrm{NaCl} / \mathrm{kg}$ beef, oven dried and lyophilized mushroom powder from water blanching produced $24.79 \%$ and $58.67 \%$ more free MDA, respectively, compared to samples with oven dried and lyophilized mushrooms blanched in ascorbic acid (Fig. 1). Ascorbic acid has antioxidant properties (Ahn \& Nam, 2004) and can inhibit LOX, leading to lower $(\mathrm{p}<0.05)$ free MDA observed.

The $15 \mathrm{~g} \mathrm{NaCl} / \mathrm{kg}$ salted raw beef control with no added mushroom powder produced $82.42 \%$ and $46.60 \%$ more free MDA compared to raw beef with oven dried and lyophilized mushrooms blanched in water, respectively. The $15 \mathrm{~g} \mathrm{NaCl} / \mathrm{kg}$ beef (1.5\%) salted raw beef 
control produced $92.74 \%$ and $59.84 \%$ more free MDA compared to raw beef with added oven dried and lyophilized mushrooms blanched in ascorbic acid. Although mushrooms blanched in ascorbic acid and water decreased free MDA by $10.31 \%$ and $13.23 \%$ on day 12 , respectively, the $2.92 \%$ difference between the two blanching methods was relatively small when compared to the 92.74\% increase in free MDA in the control compared to the blanched mushroom treatments.

Therefore, mushrooms blanched in $1 \mathrm{~g}$ ascorbic acid/100 $\mathrm{mL}$ water were not used in subsequent assays.

Addition of lyophilized and oven dried mushrooms decreased free MDA content, where, addition of oven dried mushrooms to raw ground beef lowered free MDA by $67.18 \%$ compared to lyophilized mushrooms on day 12 (Fig. 1). Due to the higher phenolic content of oven dried mushrooms compared to lyophilized mushrooms, oven dried mushrooms can inhibit lipid oxidation to a greater extent, lowering amount of free MDA produced. Therefore, the binding of MDA with bovine proteins that lowered free MDA was monitored using oven-dried mushrooms. As seen in Table 2, adding $20 \mathrm{~g}$ oven dried DAB/kg beef (2\%) to SP increased binding of MDA by $52.56-71.19 \%$ compared to the control treatments with no added DAB on each day of analysis. Similarly, Stapornkul, Prytkova, \& Were (2016) found that adding green tea increased MDA binding by $59 \%$ compared to the control with no added green tea. As seen in Fig. 1, adding DAB decreased free MDA, because rather than having free MDA in the meat matrix, the MDA was bound to the proteins in ground beef (Stapornkul, Prytkova, \& Were, 2016). The Bos taurus myoglobin in the sarcoplasmic protein is comprised of 13 histidine residues on its 154 amino acid chain, while Agaricus bisporus lectin protein, a major protein in Agaricus bisporus mushrooms, contains 1 histidine residue and 9 tyrosine residues on its 142 amino acid chain (Carrizo, Irazoqui, Lardone, Nores, Curtino, Capaldi, et al., 2004). Adding mushrooms may thus 
increase the number of amino acid potential binding sites for MDA, thereby increasing the percent MDA binding compared to the control samples with no DAB added. Mushrooms added to $\mathrm{SP}$ at $20 \mathrm{~g} \mathrm{DAB} / \mathrm{kg}$ beef had $27.57-63.95 \%$ higher binding to MDA compared to mushrooms added to SP at $10 \mathrm{~g} \mathrm{DAB} / \mathrm{kg}$ beef on day 9, which may be due to the $20 \mathrm{~g} \mathrm{DAB} / \mathrm{kg}$ beef having twice the amount of amino acid binding sites available for MDA to bind. The interaction of treatment and day was significant $(\mathrm{p}<0.05)$ for MDA binding (Table 3). The highest binding of MDA to SP was on day 9 with $15 \mathrm{~g} \mathrm{NaCl} / \mathrm{kg}$ beef (1.5\%) and $20 \mathrm{~g} \mathrm{DAB} / \mathrm{kg}$ beef (2\%) at 21.69 mg MDA/kg beef, whereas the lowest binding of MDA to SP was on day 9 with no $\mathrm{NaCl}$ and DAB added at 4.702 MDA mg/kg beef (Table 2). The higher MDA binding with $20 \mathrm{~g} \mathrm{DAB} / \mathrm{kg}$ beef and $15 \mathrm{~g} \mathrm{NaCl} / \mathrm{kg}$ beef may explain the results found in Fig. 1, where added $20 \mathrm{~g} \mathrm{DAB} / \mathrm{kg}$ beef (2\%) and $15 \mathrm{~g} \mathrm{NaCl} / \mathrm{kg}$ beef (1.5\%) lowered free MDA in raw beef. Jensen (2008) found that at high salt concentrations of $\sim 2 \%$, the ionic strength of protein may be altered to increase protein-protein interaction. This interaction could therefore decrease the percent MDA binding seen in SP samples with added $20 \mathrm{~g} \mathrm{DAB} / \mathrm{kg}$ beef and $20 \mathrm{~g} \mathrm{NaCl} / \mathrm{kg}$ beef compared to SP samples treated with $20 \mathrm{~g} \mathrm{DAB} / \mathrm{kg}$ beef (2\%) and $15 \mathrm{~g} \mathrm{NaCl} / \mathrm{kg}$ beef (1.5\%) (Table 2). As seen in Table 2, the bound MDA to SP increased from day 0 (baseline) to day 1 . However, the bound MDA to SP began to decrease between day 1 to day 9 . From day 0 to day 1 , there may have been more amino acid sites for MDA to bind to, thereby increasing amount of bound MDA to protein. However, once MDA starts to bind to protein, the number of free amino acid sites available were occupied, decreasing MDA bound to the protein after day 1 (Table 2).

\subsubsection{Binding of Volatile Aldehydes to Bovine Protein in the Presence of Mushroom Powder and $\mathrm{NaCl}$}

There was an increase in bound volatile aldehydes to protein from 20.24, 23.53, and 56.21 mg bound volatile/g SP as the carbon chain length of the aldehyde increased from propanal, 
hexanal, and octanal, respectively (Fig. 2). Perez-Juan, Flores, \& Toldra (2008) found that pork actomyosin bound to octanal to a greater extent than did hexanal, which is similar to Stapornkul, Prytkova, \& Were (2016) findings where free percent volatile compounds were in the decreasing order: pentanal $>$ hexanal $>$ heptanal $>$ octanal $>$ nonanal, suggesting that molecules with longer carbon-chain length have higher binding with protein. The binding affinity of sarcoplasmic protein to volatile aldehydes is dependent on hydrophobic interaction between the protein and aldehydes.

The addition of $10 \mathrm{~g}$ oven dried DAB/kg beef (1\%) to SP increased propanal, hexanal, and octanal binding to protein by $20.90 \%, 22.65 \%$, and $40.67 \%$, respectively compared to SP control

(Fig. 2). Stapornkul, Prytkova, \& Were, (2016) found that green tea phenolic compounds can bind near the His 64 on the surface of myoglobin, blocking potential aldehyde binding to that specific histidine. Although the phenolic compounds in green tea, such as catechin, can block volatile aldehydes from binding, the volatile aldehydes are significantly lower in molecular weight/MW compared to phenolic compounds in mushrooms such as gallic acid (MW 170.12 $\mathrm{g} / \mathrm{mol}$ ), therefore, propanal, hexanal, and octanal with MW of 58.08, 100.16, and 128.212 g/mol, respectively, are more likely to bind to the histidine sites in myoglobin compared to the higher MW phenolic compounds. In addition to the 12 histidine sites on the surface of myoglobin, the Agaricus bisporus lectin protein, a major protein in Agaricus bisporus mushrooms' additional histidine site (Carrizo, et al., 2004), could provide volatile aldehydes more histidine sites to bind to, thereby decreasing the percentage of free aldehydes. Stapornkul, Prytkova, \& Were (2016) also found through molecular docking that at His 97, octanal bound to the greatest extent at 0.92 mg/g SP compared with hexanal at $0.63 \mathrm{mg} / \mathrm{g} \mathrm{SP}$ (Stapornkul, Prytkova, \& Were, 2016). 
$314 \mathrm{~g} \mathrm{NaCl} / \mathrm{kg}$ beef (2\%) compared to the control SP for propanal, hexanal, and octanal. The binding

315 of propanal, hexanal, and octanal decreased by $0.31 \%, 0.22 \%$, and $6.69 \%$, respectively, with added $20 \mathrm{~g} \mathrm{NaCl} / \mathrm{kg}$ beef (2\%) in SP compared to SP control with no added $\mathrm{NaCl}$. Adding salt can preserve meat by inhibiting microbial growth in beef depending on the $\mathrm{NaCl}$ concentration, however, Perez-Juan, Flores, \& Toldra, (2008) found that addition of $0.05 \mathrm{M} \mathrm{NaCl}$ to protein homogenates significantly increased free volatile aldehydes compared to unsalted homogenates. The addition of $20 \mathrm{~g} \mathrm{NaCl} / \mathrm{kg}$ beef (2\%) can inhibit the activity of antioxidant enzymes, such as catalase, glutathione peroxidase, and superoxide dismutase, favoring oxidation (Pavan \& Duckett, 2013).

It was established that adding $10 \mathrm{~g} \mathrm{DAB} / \mathrm{kg}$ beef (1\%) to SP increased the binding of volatile aldehydes in SP by $20.90-40.67 \%$, whereas adding $20 \mathrm{~g} \mathrm{NaCl} / \mathrm{kg}$ beef (2\%) to SP decreased the binding of aldehydes to protein by $0.31-6.69 \%$. Although adding $20 \mathrm{~g} \mathrm{NaCl} / \mathrm{kg}$ beef (2\%) to SP decreased aldehyde binding to protein compared to SP control, adding a mixture of $10 \mathrm{~g} \mathrm{DAB} / \mathrm{kg}$ beef (1\%) and $20 \mathrm{~g} \mathrm{NaCl} / \mathrm{kg}$ beef (2\%) to SP increased binding of volatiles to protein (Fig. 2) indicating that $10 \mathrm{~g} \mathrm{DAB} / \mathrm{kg}$ beef $(1 \%)$ is an effective ingredient for increasing binding of volatile aldehydes to protein compared to the control with no added $\mathrm{NaCl}$ and mushroom. Alnoumani, Ataman, \& Were (2017) likewise found a 99\% decrease in volatile aldehydes in ground beef with added DAB compared to ground beef control with no added DAB.

The addition of DAB to ground beef has been shown to inhibit LOX and decrease production of LOX products, such as MDA and volatile aldehydes. Although DAB's antioxidative capacity in meat has been demonstrated, the addition of DAB to ground beef could affect sensory qualities. Table S1 indicated that panelists could differentiate between the sample with a $33 \%$ and $55 \%$ salt reduction that were compensated with DAB. However, no differences 
( $p>0.5)$ in the liking of saltiness, smell, juiciness, overall flavor, and overall liking were detected between control patties and patties with added DAB and 33\% less salt (Table 4) demonstrating potential replacement of $33 \%$ salt with DAB.

\section{Summary and Conclusions}

Oven dried mushroom powder yielded a higher phenolic content compared to lyophilization, which accounted for a decrease in free MDA and volatile aldehydes produced. The addition of DAB increased the binding of LOX products to sarcoplasmic protein. The addition of $20 \mathrm{~g} \mathrm{NaCl} / \mathrm{kg}$ beef (2\%) to raw beef acted as a pro-oxidant, however, addition of $15 \mathrm{~g}$ $\mathrm{NaCl} / \mathrm{kg}$ beef (1.5\%) to raw beef increased the binding of LOX products, an indication that salt concentration can affect lipid oxidation depending on concentration. The sodium chloride concentrations that promote or have no negative effect on oxidation warrants further investigation. The molecular basis determining if release of ferrous iron from ground beef or competition of salt with anti- or pro-oxidants to explain results obtained should be explored. Improving the knowledge and understanding of naturally sourced antioxidants, such as Agaricus bisporus mushrooms utilized in the meat industry is important, as use of mushroom powder can improve the chemical shelf life of raw beef at the retail and consumer level and can compensate for $\mathrm{NaCl}$ reduction without negatively affecting sensory acceptance. Possible mushroom powder applications may include a seasoning salt blend for beef products to reduce sodium chloride content.

\section{Conflict of Interest}

Authors do not have any conflict of interest.

\section{Acknowledgements}


This work was supported by Chapman University's Summer Undergraduate Research

Fellowship (SURF). The authors would also like to thank B\&C Fresh Sales (Orange, CA) for

providing the mushrooms.

\section{References}

363

364

365

366

367

368

369

370

Alnoumani, H., Ataman, Z. A., \& Were, L. (2017). Lipid and protein antioxidant capacity of dried Agaricus bisporus in salted cooked ground beef. Meat Science, 129, 9-19.

Ahn, D. U., \& Nam, K. C. (2004). Effects of ascorbic acid and antioxidants on color, lipid oxidation and volatiles of irradiated ground beef. Radiation Physics and Chemistry, 71, 151-156.

Buzby, J., Bentley, J., Padera, B., Campuzano, J., \& Ammon, C. (2016). Updated Supermarket Shrink Estimates for Fresh Foods and Their Implications for ERS Loss-Adjusted Food Availability Data. U.S. Department of Agriculture, Economic Research Service, EIB-155.

Brockhoff, P. B., \& Linander, C. B. (2017). Analysis of the Data Using the R Package sensR. Discrimination Testing in Sensory Science: a Practical Handbook, 303-344.

Carrizo, M. E., Irazoqui, F. J., Lardone, R. D., Nores, G. A., Curtino, J. A., Capaldi, S., Perduca, M., \& Monaco, H. L. (2004). Crystallization and preliminary X-ray study of the common edible mushroom (Agaricus bisporus) lectin. Acta Crystallographica Section DBiological Crystallography, 60, 718-720.

Choi, Y., Lee, S. M., Chun, J., Lee, H. B., \& Lee, J. (2006). Influence of heat treatment on the antioxidant activities and polyphenolic compounds of Shiitake (Lentinus edodes) mushroom. Food Chemistry, 99, 381-387.

da Silva, A. N., da Silva, R., Ferreira, M. A. M., Minim, V. P. R., da Costa, T. D. T., \& Perez, R. (2013). Performance of hedonic scales in sensory acceptability of strawberry yogurt. Food Quality and Preference, 30, 9-21.

Dubost, N. J., Ou, B., \& Beelman, R. B. (2007). Quantification of polyphenols and ergothioneine in cultivated mushrooms and correlation to total antioxidant capacity. Food Chemistry, 105(2), 727-735.

Ferreira, I., Barros, L., \& Abreu, R. M. V. (2009). Antioxidants in Wild Mushrooms. Current Medicinal Chemistry, 16, 1543-1560.

Font-I-Furnols, M., \& Guerrero, L. (2014). Consumer preference, behavior and perception about meat and meat products: An overview. Meat Science, 98(3), 361-371.

Ghahremani-Majd, H., \& Dashti, F. (2015). Chemical composition and antioxidant properties of cultivated button mushrooms (Agaricus bisporus). Horticulture Environment and Biotechnology, 56, 376-382.

Giri, S. K., \& Prasad, S. (2007). Drying kinetics and rehydration characteristics of microwavevacuum and convective hot-air dried mushrooms. Journal of Food Engineering, 78, 512521.

Ishii, R., O'Mahony, M., \& Rousseau, B. (2014). Triangle and tetrad protocols: Small sensory differences, resampling and consumer relevance. Food Quality and Preference, 31, 4955. 
Jensen, J. H. (2008). Calculating $\mathrm{pH}$ and salt dependence of protein-protein binding. Current Pharmaceutical Biotechnology, 9, 96-102.

Lespinard, A. R., Goni, S. M., Salgado, P. R., \& Mascheroni, R. H. (2009). Experimental determination and modelling of size variation, heat transfer and quality indexes during mushroom blanching. Journal of Food Engineering, 92, 8-17.

Mariutti, L. R. B., \& Bragagnolo, N. (2017). Influence of salt on lipid oxidation in meat and seafood products: A review. Food Research International, 94, 90-100.

Mphahlele, R. R., Fawole, O. A., Makunga, N. P., \& Opara, U. L. (2016). Effect of drying on the bioactive compounds, antioxidant, antibacterial and antityrosinase activities of pomegranate peel. BMC Complementary and Alternative Medicine, 16, 1-12.

Oikonomopoulou, V. P., Krokida, M. K., \& Karathanos, V. T. (2011). The influence of freeze drying conditions on microstructural changes of food products. $11^{\text {th }}$ International Congress on Engineering and Food (Icef11), 1, 647-654.

Pavan, E., \& Duckett, S. K. (2013). Fatty acid composition and interrelationships among eight retail cuts of grass-feed beef. Meat Science, 93, 371-377.

Perez-Juan, M., Flores, M., \& Toldra, F. (2008). Effect of pork meat proteins on the binding of volatile compounds. Food Chemistry, 108, 1226-1233.

RCoreTeam. (2013). R: A language and environment for statistical computing. R Foundation for Statistical Computing, Vienna, Austria. http://www.R-project.org/.

Rojas, M. C., \& Brewer, M. S. (2007). Effect of natural antioxidants on oxidative stability of cooked, refrigerated beef and pork. Journal of Food Science, 72, S282-S288.

Sammet, K., Duehlmeier, R., Sallmann, H. P., Von Canstein, C., Von Mueffling, T., \& Nowak, B. (2006). Assessment of the antioxidative potential of dietary supplementation with alpha-tocopherol in low-nitrite salami-type sausages. Meat Science, 72, 270-279.

Stapornkul, N., Prytkova, T., \& Were, L. (2016). Effect of green tea on interaction of lipid oxidation products with sarcoplasmic and myofibrillar protein homogenates extracted from bovine top round muscle. Food Research International, 89, 1038-1045.

Su, D. X., Zhang, R. F., Hou, F. L., Zhang, M. W., Guo, J. X., Huang, F., Deng, Y. Y., \& Wei, Z. C. (2014). Comparison of the free and bound phenolic profiles and cellular antioxidant activities of litchi pulp extracts from different solvents. Bmc Complementary and Alternative Medicine, 14.

Varvara, M., Bozzo, G., Celano, G., Disanto, C., Pagliarone, C. N., \& Celano, G. V. (2016). The use of ascorbic acid as a food additive: technical-legal issues. Italian Journal of Food Safety, 5, 7-10. 


\begin{tabular}{llllll}
\hline Source & DF & Type II SS & Mean Square & F & Pr $>$ F \\
\hline Day $^{\mathrm{a}}$ & 4 & 0.08092 & 0.02031 & 1239.77 & $<0.0001$ \\
Salt $^{\mathrm{b}}$ & 1 & 0.00015 & 0.00015 & 9.30000 & 0.0037 \\
Treatment $^{\mathrm{c}}$ & 4 & 0.05211 & 0.01303 & 798.400 & $<0.0001$ \\
Day*Salt & 4 & 0.00294 & 0.00294 & 45.1100 & $<0.0001$ \\
Treatment*Day & 16 & 0.06021 & 0.00376 & 230.610 & $<0.0001$ \\
Treatment*Salt & 4 & 0.00039 & 0.00009 & 6.06000 & 0.0005 \\
Treatment*Day*Salt & 16 & 0.00337 & 0.00337 & 12.9100 & $<0.0001$ \\
Error & 50 & 0.00082 & & & \\
Corrected Total & 99 & 0.20093 & & &
\end{tabular}

1 Table 1 Analysis of Variance Model of Free Malondialdehyde in Ground Beef

2 a Days included 1, 3, 6, 9, and 12 of refrigerated storage,

$3{ }^{\mathrm{b}}$ salt included $15 \mathrm{~g} \mathrm{NaCl} / \mathrm{kg}$ beef $(1.5 \%)$ and $20 \mathrm{~g} \mathrm{NaCl} / \mathrm{kg}$ beef (2\%)

$4{ }^{\mathrm{c}}$ Treatments included beef with oven dried and lyophilized mushrooms blanched in $1 \%$ ascorbic

5 acid and water with $15 \mathrm{~g} \mathrm{NaCl} / \mathrm{kg}$ beef (1.5\%) and $20 \mathrm{~g} \mathrm{NaCl} / \mathrm{g}$ beef (2\%). 
Table 2 Bound MDA (mg/kg protein) in refrigerated $\left(4^{\circ} \mathrm{C}\right)$ bovine sarcoplasmic protein $(\mathrm{SP})$ with added oven dried Agaricus bisporus (DAB) mushrooms and salt ( $\mathrm{NaCl}$ ).

\begin{tabular}{|c|c|c|c|c|c|}
\hline \multirow[b]{2}{*}{ Samples } & \multicolumn{5}{|c|}{ Mean \pm SD of Bound MDA/Protein $(\mathrm{mg} / \mathrm{kg})$} \\
\hline & Baseline (Day 0) & Day 1 & Day 3 & Day 6 & Day 9 \\
\hline \multicolumn{6}{|c|}{ Unsalted Sarcoplasmic Protein (SP) } \\
\hline Sarcoplasmic Protein (SP) & $4.71 \pm 0.021^{\mathrm{h}}$ & $16.42 \pm 0.064^{\mathrm{g}}$ & $7.840 \pm 0.099^{\mathrm{i}}$ & $11.09 \pm 0.035^{\mathrm{f}}$ & $4.702 \pm 0.001^{\mathrm{g}}$ \\
\hline $\mathrm{SP}+10 \mathrm{~g} \mathrm{DAB} / \mathrm{kg}$ beef & $6.10 \pm 0.014^{\mathrm{e}}$ & $17.43 \pm 0.049^{\mathrm{f}}$ & $17.23 \pm 0.021^{\mathrm{d}}$ & $14.11 \pm 0.022^{\mathrm{e}}$ & $11.82 \pm 0.014^{\mathrm{d}}$ \\
\hline $\mathrm{SP}+20 \mathrm{~g} \mathrm{DAB} / \mathrm{kg}$ beef & $6.99 \pm 0.016^{\mathrm{d}}$ & $20.08 \pm 0.028^{\mathrm{b}}$ & $20.58 \pm 0.057^{\mathrm{a}}$ & $18.78 \pm 0.085^{\mathrm{b}}$ & $16.32 \pm 0.042^{\mathrm{c}}$ \\
\hline \multicolumn{6}{|c|}{$15 \mathrm{~g} \mathrm{NaCl/kg} \mathrm{beef} \mathrm{Salted} \mathrm{Sarcoplasmic} \mathrm{Protein} \mathrm{(SP)}$} \\
\hline Sarcoplasmic Protein (SP) & $7.90 \pm 0.014^{\mathrm{b}}$ & $15.02 \pm 0.148^{\mathrm{h}}$ & $12.65 \pm 0.078^{\mathrm{h}}$ & $9.220 \pm 0.134^{\mathrm{g}}$ & $7.508 \pm 0.221^{\mathrm{f}}$ \\
\hline $\mathrm{SP}+10 \mathrm{~g} \mathrm{DAB} / \mathrm{kg}$ beef & $7.35 \pm 0.021^{\mathrm{c}}$ & $18.47 \pm 0.021^{\mathrm{d}}$ & $20.01 \pm 0.014^{\mathrm{b}}$ & $16.76 \pm 0.070^{\mathrm{d}}$ & $7.820 \pm 0.007^{\mathrm{f}}$ \\
\hline $\mathrm{SP}+20 \mathrm{~g} \mathrm{DAB} / \mathrm{kg}$ beef & $8.49 \pm 0.0007^{\mathrm{a}}$ & $19.75 \pm 0.0007^{\mathrm{c}}$ & $16.73 \pm 0.007^{\mathrm{e}}$ & $18.08 \pm 0.049^{\mathrm{c}}$ & $21.69 \pm 0.049^{\mathrm{a}}$ \\
\hline \multicolumn{6}{|c|}{$20 \mathrm{~g} \mathrm{NaCl} / \mathrm{kg}$ beef Salted Sarcoplasmic Protein (SP) } \\
\hline Sarcoplasmic Protein (SP) & $4.99 \pm 0.078^{\mathrm{g}}$ & $17.36 \pm 0.042^{\mathrm{f}}$ & $13.61 \pm 0.052^{\mathrm{g}}$ & $6.806 \pm 0.006^{h}$ & $7.898 \pm 0.023^{\mathrm{f}}$ \\
\hline $\mathrm{SP}+10 \mathrm{~g} \mathrm{DAB} / \mathrm{kg}$ beef & $5.35 \pm 0.035^{\mathrm{f}}$ & $18.19 \pm 0.071^{\mathrm{e}}$ & $15.93 \pm 0.014^{\mathrm{f}}$ & $14.08 \pm 0.007^{\mathrm{e}}$ & $8.239 \pm 0.018^{\mathrm{e}}$ \\
\hline $\mathrm{SP}+20 \mathrm{~g} \mathrm{DAB} / \mathrm{kg}$ beef & $5.40 \pm 0.035^{\mathrm{f}}$ & $20.47 \pm 0.057^{\mathrm{a}}$ & $19.69 \pm 0.042^{\mathrm{c}}$ & $21.38 \pm 0.049^{\mathrm{a}}$ & $16.65 \pm 0.007^{\mathrm{b}}$ \\
\hline
\end{tabular}

Means in the same column with the same letters (a-e) are not significantly different 


\begin{tabular}{llllll}
\hline Source & DF & Type II SS & Mean Square & F & Pr $>$ F \\
\hline Day $^{\mathrm{a}}$ & 4 & 1508.69 & 377.17 & 102697 & $<0.001$ \\
Salt $^{\mathrm{b}}$ & 2 & 13.9202 & 6.9901 & 1903.27 & $<0.001$ \\
Treatment $^{\mathrm{c}}$ & 2 & 709.784 & 354.89 & 96630.1 & $<0.001$ \\
Day*Salt & 8 & 27.6858 & 3.4607 & 942.290 & $<0.001$ \\
Treatment*Day & 8 & 298.711 & 37.339 & 10166.66 & $<0.001$ \\
Treatment*Salt & 4 & 14.6587 & 3.6647 & 997.8200 & $<0.001$ \\
Treatment*Day*Salt & 16 & 157.358 & 9.8349 & 2677.850 & $<0.001$ \\
Error & 45 & & & & \\
Corrected Total & 89 & & & &
\end{tabular}

1 Table 3 Analysis of Variance Model of Bound Malondialdehyde in Sarcoplasmic Proteins.

$2{ }^{\mathrm{a}}$ Days included $1,3,6$, and 9 of $4^{\circ} \mathrm{C}$ refrigerated storage

$3 \quad{ }^{\mathrm{b}}$ Salt included $0 \mathrm{~g} \mathrm{NaCl} / \mathrm{kg}$ beef $(0 \%), 15 \mathrm{~g} \mathrm{NaCl} / \mathrm{kg}$ beef $(1.5 \%)$, and $20 \mathrm{~g} \mathrm{NaCl} / \mathrm{kg}$ beef $(2 \%)$

$4{ }^{\mathrm{a}}$ Treatments included sarcoplasmic protein with $\pm 0 \mathrm{~g} \mathrm{DAB} / \mathrm{kg}$ beef $(0 \%), 10 \mathrm{~g} \mathrm{DAB} / \mathrm{kg}$ beef

$5(1 \%)$ and $20 \mathrm{~g} \mathrm{DAB} / \mathrm{kg}$ beef $(2 \%)$ and $\pm 0 \mathrm{~g} \mathrm{NaCl} / \mathrm{kg}$ beef $(0 \%), 15 \mathrm{~g} \mathrm{NaCl} / \mathrm{kg}$ beef $(1.5 \%)$ or 20 $6 \mathrm{~g} \mathrm{NaCl} / \mathrm{kg}$ beef $(2 \%)$. 
8 Table 4 Hedonic test results (Mean \pm SD) of adding $20 \mathrm{~g} \mathrm{DAB} / \mathrm{kg}$ beef (2\%) to beef patties with

$933 \%$ salt reduction compared to the control.

\begin{tabular}{|c|c|c|c|c|c|}
\hline & & Saltiness & Smell & Juiciness & Overall flavor \\
\hline \multicolumn{6}{|c|}{ First Trial: NaCl was reduced by $33 \%$} \\
\hline \multirow{3}{*}{ Day 1} & Control & $5.49 \pm 1.56$ & $5.23 \pm 1.26$ & $5.34 \pm 1.85$ & $5.23 \pm 1.78$ \\
\hline & DAB & $5.37 \pm 1.82$ & $5.26 \pm 1.54$ & $4.66 \pm 2.00$ & $5.69 \pm 1.89$ \\
\hline & p-value & 0.768 & 0.93 & 0.148 & 0.302 \\
\hline \multirow{3}{*}{ Day 2} & Control & $5.03 \pm 1.58$ & $5.31 \pm 1.67$ & $4.82 \pm 1.78$ & $5.20 \pm 1.90$ \\
\hline & DAB & $6.11 \pm 1.76$ & $5.23 \pm 1.54$ & $5.26 \pm 1.68$ & $5.86 \pm 1.91$ \\
\hline & p-value & 0.0004 & 0.778 & 0.150 & 0.052 \\
\hline \multicolumn{6}{|c|}{ Second Trial: $\mathrm{NaCl}$ was reduced by $\mathbf{5 0 \%}$} \\
\hline \multirow{3}{*}{ Day 1} & Control & $6.34 \pm 1.26$ & $5.74 \pm 1.46$ & $5.89 \pm 1.55$ & $6.57 \pm 1.42$ \\
\hline & $\mathrm{DAB}$ & $5.77 \pm 1.68$ & $5.51 \pm 1.63$ & $4.26 \pm 1.92$ & $5.31 \pm 1.69$ \\
\hline & p-value & 0.118 & 0.538 & 0.0004 & 0.0018 \\
\hline \multirow{3}{*}{ Day 3} & Control & $6.55 \pm 1.54$ & $5.67 \pm 1.90$ & $6.57 \pm 1.38$ & $6.80 \pm 1.31$ \\
\hline & DAB & $5.80 \pm 1.54$ & $5.27 \pm 1.75$ & $4.29 \pm 1.71$ & $5.39 \pm 1.71$ \\
\hline & p-value & 0.019 & 0.282 & $<0.0001$ & $<0.0001$ \\
\hline
\end{tabular}

10

11 


\section{1. Figure Captions}

2 Fig. 1. Thiobarbituric Acid Reactive Substances $(\mathrm{mg} / \mathrm{kg}$ ) values of raw ground beef with added 3 oven dried and lyophilized mushroom powder blanched in $1 \mathrm{~g}$ ascorbic acid/100 $\mathrm{mL}$ water (1\%) 4 ascorbic acid (AA) or water solutions with different salt concentrations $(1.5 \%$ or $2 \%)$ stored at 5 4C for 12 days. Means with the same letters are not significantly different on day 12.

6

Fig. 2. Bound Volatiles $(\mathrm{mg} / \mathrm{g}$ protein $)$ in refrigerated $\left(4^{\circ} \mathrm{C}\right)$ bovine sarcoplasmic protein $(\mathrm{SP})$ 8 with and without $10 \mathrm{~g}$ oven dried Agaricus bisporus (DAB) mushroom powder/Kg beef (1\%) 9 and with and without $20 \mathrm{~g}$ salt $(\mathrm{NaCl}) / \mathrm{Kg}$ beef $(2 \% \mathrm{NaCl})$. 

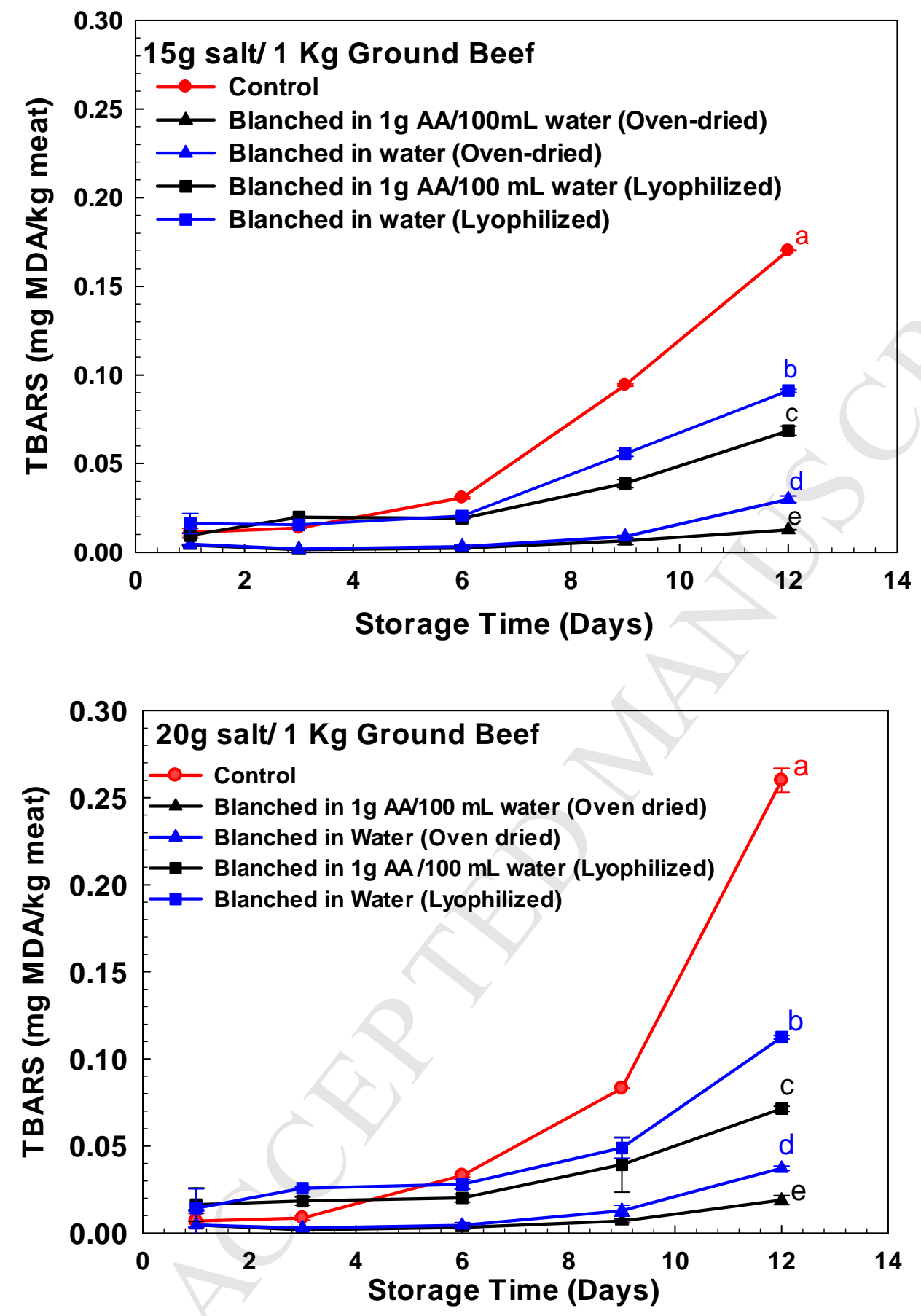

Fig. 1. 


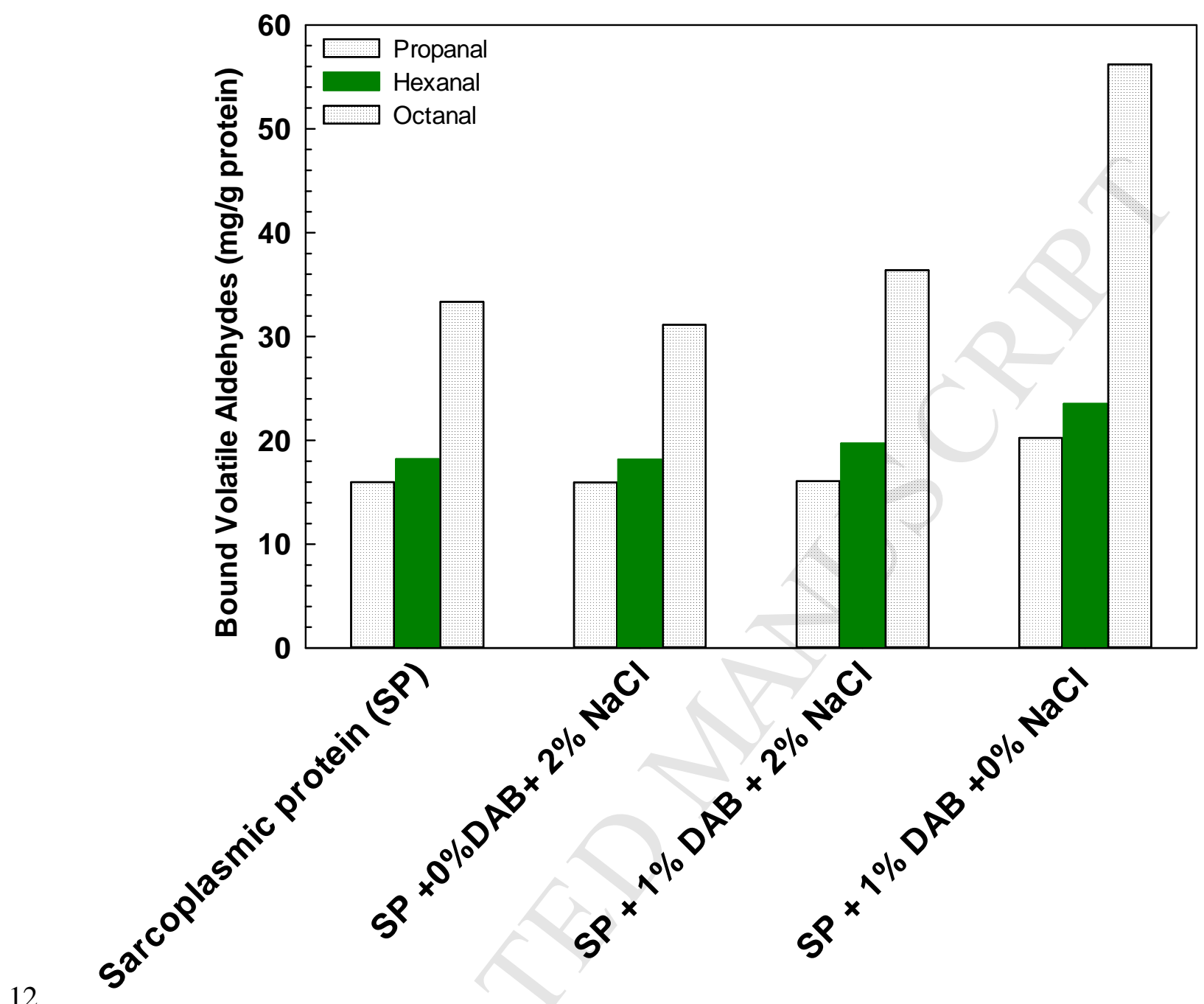

13

14

Fig. 2. 
1 Highlights

2 - Free malondialdehyde increased with storage time

3 - Oven dried mushroom powder had greater antioxidant capacity than lyophilized powder

4 - Antioxidant capacity and lipid oxidation product binding was positively correlated

5 - An increase in $\mathrm{NaCl}$ from $1.5 \%$ to $2 \%$ increased free lipid oxidation products

6 - $2 \%$ mushroom powder compensated for $33 \%$ salt reduction in beef patties. 